\title{
Reproduction and fecundity of the mussel Mytilus edulis at Helgoland (North Sea)
}

\author{
M. Sprung \\ Biologische Anstalt Helgoland (Meeresstation); \\ D-2192 Helgoland, Federal Republik of Germany
}

\begin{abstract}
The reproductive cycle of a Mytilus edulis population in the lower tidal zone at the island of Helgoland from Spring 1980 to Summer 1981 is described. In both years the spawning period extended from the end of April until the end of June at water temperatures between $6^{\circ}$ and $14{ }^{\circ} \mathrm{C}$. The gametes were built up again in autumn and most individuals were mature in February. Sex ratio did not differ significantly from 1:1. Fecundity, egg diameter and gamete weight of this and another population in the subtidal zone were assessed and size frequency distribution of shell lengths was established. Based on data of body weight prior to spawning, the following tendencies could be outlined: animals of the intertidal population had significantly smaller eggs than those from the subtidal area. Although the soft body biomass per unit area of the subtidal population was nearly double that of the tidal, their annual egg output was nearly the same $\left(2.3 \times 10^{9}\right.$ eggs $\left.\mathrm{m}^{-2}\right)$. This was achieved by a smaller size at the onset of sexual maturation $(18 \mathrm{~mm}$ instead of $30 \mathrm{~mm}$ shell length) and a higher egg output at comparable shell lengths in the intertidal. In both populations, large animals contributed most to gamete production, although they did not necessarily dominate in biomass.
\end{abstract}

\section{INTRODUCTION}

It is a well known phenomenon that recruitment by means of a planktonic larva is correlated with a high gamete production (Crisp, 1974). This holds true, also for the mussel Mytilus edulis L. which forms a dominating element in many tidal habitats of marine coasts.

The anatomy of their gonads has been described by Field (1922) and White (1937): the reproductive tissue extends nearly through the whole body except the foot, the gills and the muscles. Thus, the gonads form a considerable part of the body weight prior to spawning. Widdows (1978), for example, estimated that they can contribute up to $35 \%$ of the soft body weight. Thompson (1979) calculated the reproductive tissue as 20 to $59 \%$ increasing with mussel size, and Mix et al. (1982) obtained a value of 11 to $20 \%$ of the tissue weight for mussels of $40-60 \mathrm{~mm}$ shell length. However, exact estimates of the gamete output of mussels of various sizes have been rare (see e.g. Mateeva, 1948 or Thompson, 1979). Beyond this, in few papers have fecundity data been related to populations. Only Griffiths $(1977,1981)$ made some estimates for a population of Choromytilus meridionalis at South African coasts and Kautsky (1982) for a population of $M$. edulis in a brackish water environment near Askø (Sweden).

The reproductive cycle of mussels can be followed by an assessment of the morpho- 
logy of its gonads. This idea was first postulated by Johnstone (1898) and developed further by Chipperfield (1953). The most detailed schedules for classification have been published by Lubet (1957), Wilson \& Hodgkin (1967), Lunetta (1969) and Seed (1969).

Whereas for other localities the reproductive cycle of Mytilus has been described in this way in detail (e.g. the Atlantic coast of France by Lubet, 1957, 1959; the coasts of England by Seed, 1969, 1975), only rather general statements about its reproduction in the German Bight have been made by few authors. Kändler (1926), for example, found its larvae in the plankton from April to December, and Werner (1940) concluded from plankton samples that they would spawn from spring to autumn. The most precise information dates are from Kühl (1972), who observed spawning activity in the Elbe estuary near Cuxhaven from May to June and found its larvae in the plankton from May to September.

Thus, there is a gap in the knowledge we possess of this species, especially concerning its reproductive cyle in the German Bight, and a lack of fecundity data in general.

\section{MATERIALS AND METHODS}

\section{Gonad cycle}

Every fortnight from Spring 1980 to Summer 1981, a sample of 50 specimens $(40 \mathrm{~mm}$ shell length) was removed from a mussel bank in the lower tidal zone of the rocky shore of Helgoland. Only in autumn and winter was the sampling frequency reduced to 4week-intervals.

Gonad tissue of 25 of these animals derived from the mantle was crushed on a slide and classified under a microscope according to Chipperfield (1953) and Bayne \& Thomspon (1970):

Stage 0: thin mantle; no gonads detectable; or: the animal has just spawned (checked mantle). Stage 1: thick mantle; no gonads dectectable. Stage 2: gonads with unripe gametes can be detected in the mantle (sperms not motile; the germinal vesicles of less than a quarter of the eggs observed burst in seawater). Stage 3: gonads with ripe gametes can be detected in the mantle (most sperms motile; the germinal vesicle of more than a quarter of the eggs observed burst in seawater).

The other 25 animals were put separately in water of $18^{\circ} \mathrm{C}$ with vivid aeration to test the effect of this spawning stimulus. In samples taken after 31 July 1980 this stimulus was made more effective by keeping them at $6^{\circ} \mathrm{C}$ for a fortnight before this procedure.

The surface temperature of the water, published every day by the meteorological station at Helgoland, was noted on every sample date.

\section{Fecundity estimates}

Smaller animals of the tidal population were also examined and, in addition, animals of various sizes of a subtidal population from a breakwater off "HelgolandDüne". The latter were conditioned for up to 2 months at about $8{ }^{\circ} \mathrm{C}$ with Isochrysis galbana and Dunaliella tertiolecta as food for larval rearing experiments. Spawning was initiated by the stimulus described above.

Only animals showing vigorous spawning activity were evaluated. The gametes 
were counted in a Coulter Counter (Model $\mathrm{TA}_{\amalg}$ ) after appropriate dilution in $0.45 \mu \mathrm{m}$ filtered seawater; a $280 \mu \mathrm{m}$ tube was applied for the eggs and a $100 \mu \mathrm{m}$ tube for the sperm, subtracting a blank value. Routinely, the mean diameter of 10 eggs was assessed under a microscope by means of a micrometer.

For weight determinations, a known quantity of gametes was filtered on preweighed glass fibre filters, freeze dried for at least $3 \mathrm{~h}$ and weighed on a Perkin Elmer balance (AD-2) with an accuracy of $\pm 1 \mu \mathrm{g}$. The eggs were washed on the filter with double destilled water. This procedure was omitted with the sperm, because this leads to a loss in organic substance as preliminary experiments showed. The weight was calculated with respect to blank values (only $0.45 \mu \mathrm{m}$ filtered seawater) and the ash content of the sample (weight after $3 \mathrm{~h}$ at $500^{\circ} \mathrm{C}$ in a muffle oven).

The structure of these two populations was examined in July 1981: areas of $152 \mathrm{~cm}^{2}$ were removed from the substrate, a size frequency distribution established and the data extrapolated to $1 \mathrm{~m}^{2} .4$ samples were taken at low water in the tidal zone, 6 samples by SCUBA diving in the subtidal zone.

\section{RESULTS}

\section{Gonad cycle}

During both years, the mussels showed spawning activity from the end of April until the end of June at water temperatures between $6^{\circ}$ and $14^{\circ} \mathrm{C}$ (Fig. 1). This was more obvious in Spring 1981 than in Spring 1980: after initial spawning which ended in the middle of May, the gonads recovered until the beginning of June before they were completely emptied. Subsequently, most animals stayed in a sexually indifferent stage;

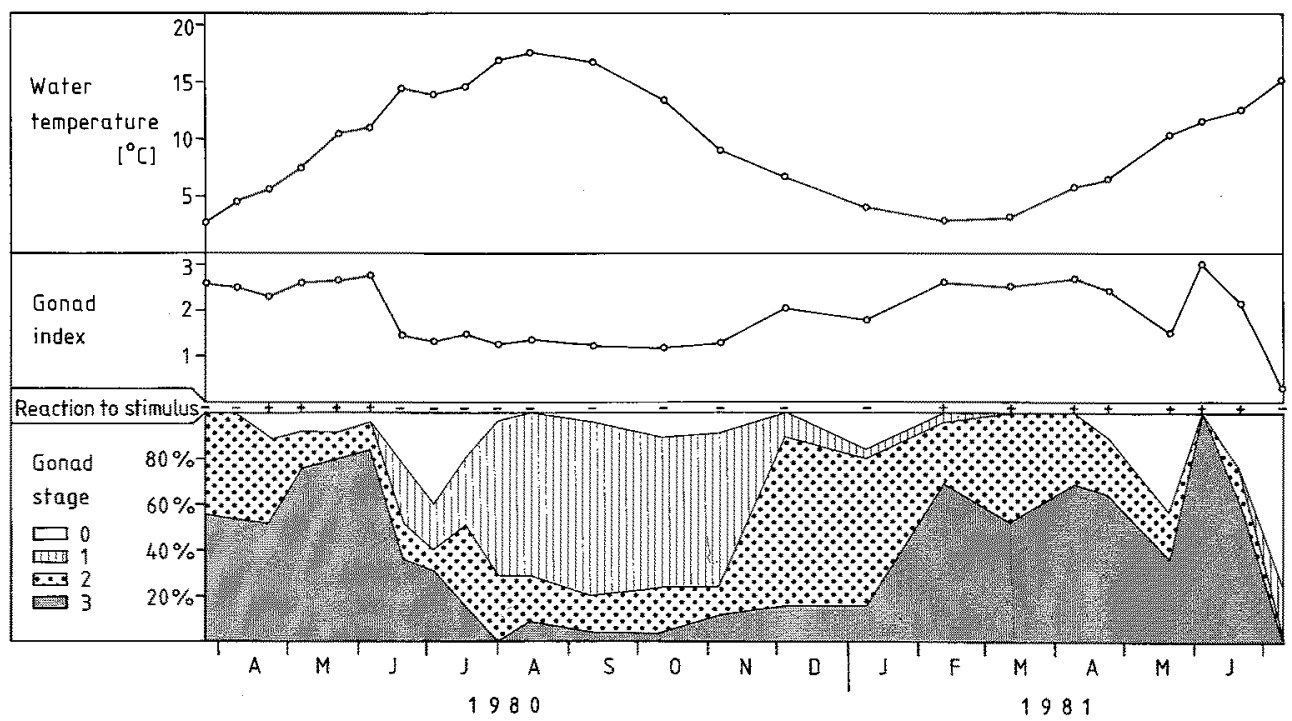

Fig. 1. Mytilus edulis: Gonad cycle during the period of observation; water surface temperature at the sample date, gonad index calculated as mean gonad stage, response to a spawning stimulus $(+:$ at least one animal spawned) and gonad stage as described in the text 
the gametes were built up again in November. Many animals were morphologically ripe as early as February. From this time on, some animals showed a positive reaction to a spawning stimulus after the pretreatment described above.

For the estimation of the sex ratio, only the 13 samples were evaluated where the sex of nearly each animal could be recognized: of the 25 mussels examined, $11.8 \pm 2.9$ were males and $13.2 \pm 2.9$ were females (mean \pm standard deviation). This result reveals a
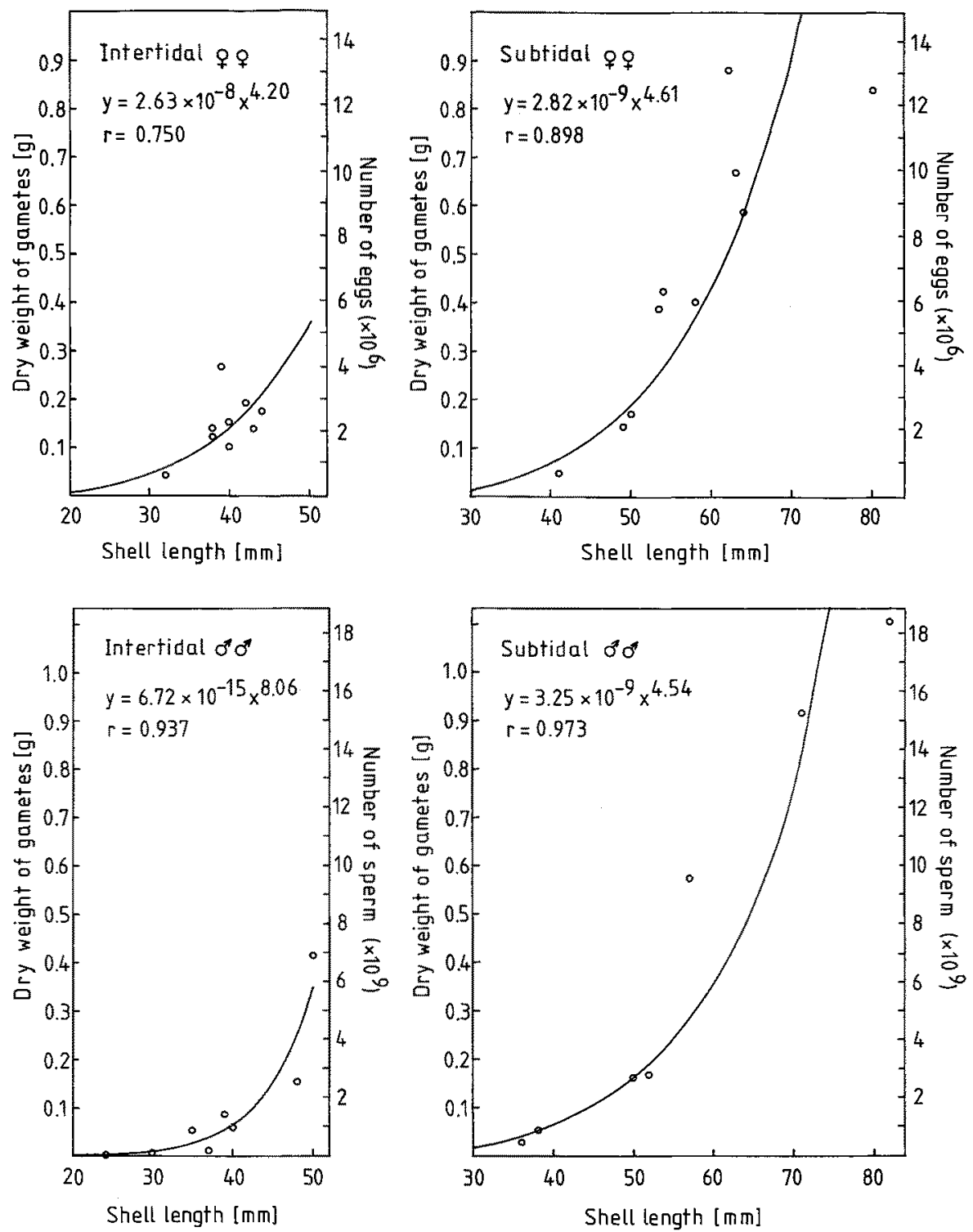

Fig. 2. Mytilus edulis: Gamete output of specimens of the intertidal and subtidal population; estimated data from gamete counts $(1 \mathrm{egg} \approx 67.4 \mathrm{ng} ; 1 \mathrm{sperm} \wedge 6.0 \mathrm{pg})$ and calculated graphs; y: dry weight of the gametes $(\mathrm{g})$; $\mathrm{x}$ : shell length $(\mathrm{mm})$; $\mathrm{r}$; correlation coefficient 
slight but insignificant (95\%-level) dominance of the female animals of 0.53:0.47. The calculations on the egg output of the populations (see below) are based on this sex ratio.

In the tidal population, sexual maturity was first observed in specimens of $18 \mathrm{~mm}$ shell length; in the subtidal population, in specimens of $30 \mathrm{~mm}$ shell length in a sample taken in March 1981.

\section{Fecundity}

Egg and sperm numbers and the fitted graphs are given in Figure 2. The weight determinations indicated the following results (mean \pm standard deviation; $\mathbf{n}$ : number of estimates):

1 egg ( $78 \mu \mathrm{m}$ diameter):

$67.4 \pm 6.1 \mathrm{ng}$ dry weight; $\mathrm{n}=7$

1 sperm:

$6.0 \pm 1.1$ pg dry weight; $n=4$.

Neither sperms nor eggs revealed any significant ash content.
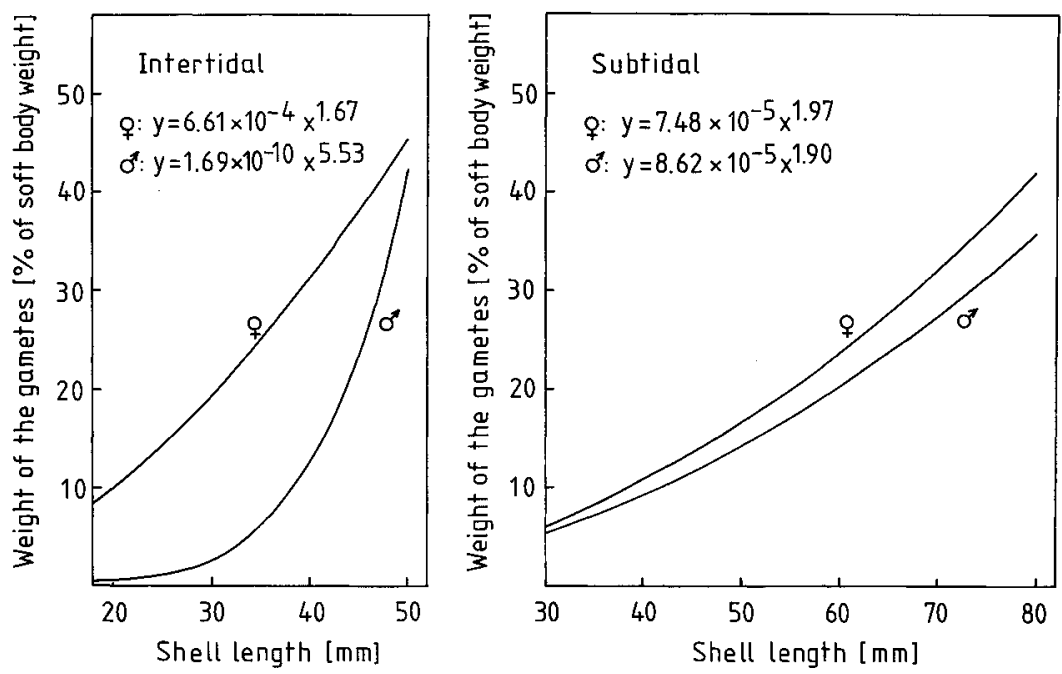

Fig. 3. Mytilus edulis: Gamete weight (percentage of the tissue weight) as a function of the shell length; calculated from data given in text and Figure $2 ; \mathrm{y}$ : gamete weight (percentage of the tissue weight); $x$ : shell length (mm)

The calculations on the relative gamete weight are based on data from Sprung (1980) for the tissue dry weight of the animals in both populations prior to spawning in Spring 1979:

$$
\begin{aligned}
& y=3.98 \times 10^{-5} \times 2.53 \text { (intertidal) } \\
& y=3.77 \times 10^{-5} \times{ }^{2.64} \text { (subtidal) }
\end{aligned}
$$

$y$ : tissue dry weight $(\mathrm{g}), \mathrm{x}$ : shell length $(\mathrm{mm})$

The mean egg diameter of the tidal animals was significantly (95\%-level) smaller than that of the subtidal mussels (n: number of animals evaluated)

$73.0 \pm 3.9 \mu \mathrm{m}$ diameter; $\mathbf{n}=\mathbf{9}$ (intertidal)

$77.1 \pm 2.3 \mu \mathrm{m}$ diameter; $\mathbf{n}=10$ (subtidal) 

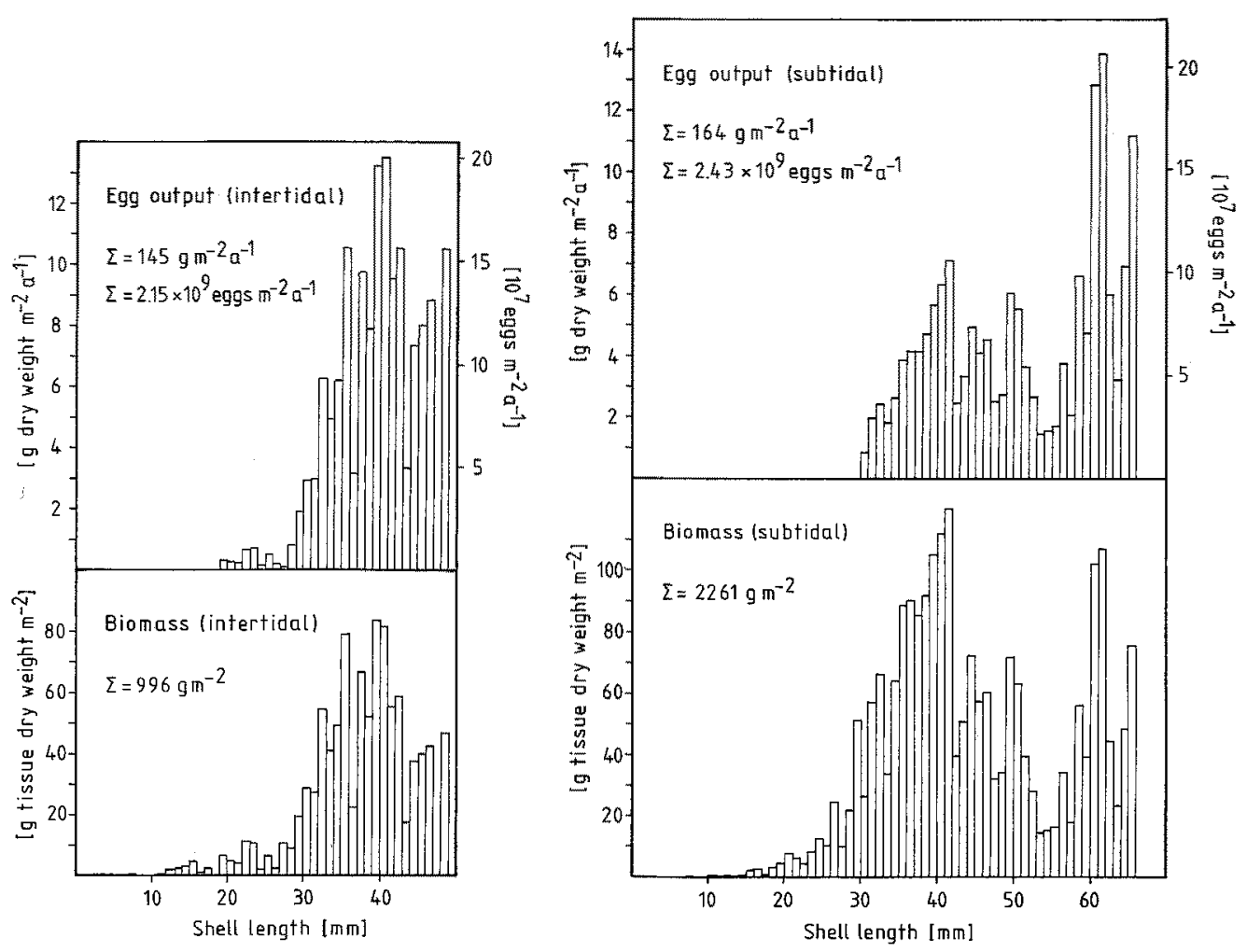

Fig. 4. Mytilus edulis: Contribution of $1 \mathrm{~mm}$ size classes to egg output and tissue biomass of the subtidal and the intertidal population (absolute values); calculated from a size frequency distribution and data given in text and Figure 2

In further extrapolations the same weight was assumed for both the intertidal and the subtidal animals, because more detailed data on the egg weight were lacking.

Figure 4 demonstrates that the subtidal population had a higher biomass. In contrast, both populations produced nearly the same amount of eggs per unit area. This is achieved by two mechanisms: smaller animals are already sexually mature and specimens of the same shell length show a greater egg output in the intertidal population than in the subtidal.

The largest animals (e.g. those of $40-45 \mathrm{~mm}$ shell length in the intertidal and of $60-65 \mathrm{~mm}$ shell length in the subtidal population) do not necessarily dominate in biomass. Nevertheless, it is these animals which contribute most to the egg output of both populations.

\section{DISCUSSION}

It is widely accepted that temperature is the most important factor controlling the reproduction of marine molluscs (Giese, 1959). The critical temperatures in the reproductive cycle of Mytilus edulis have been reported as indicated in Table 1. Generally, they agree with those observed here. 


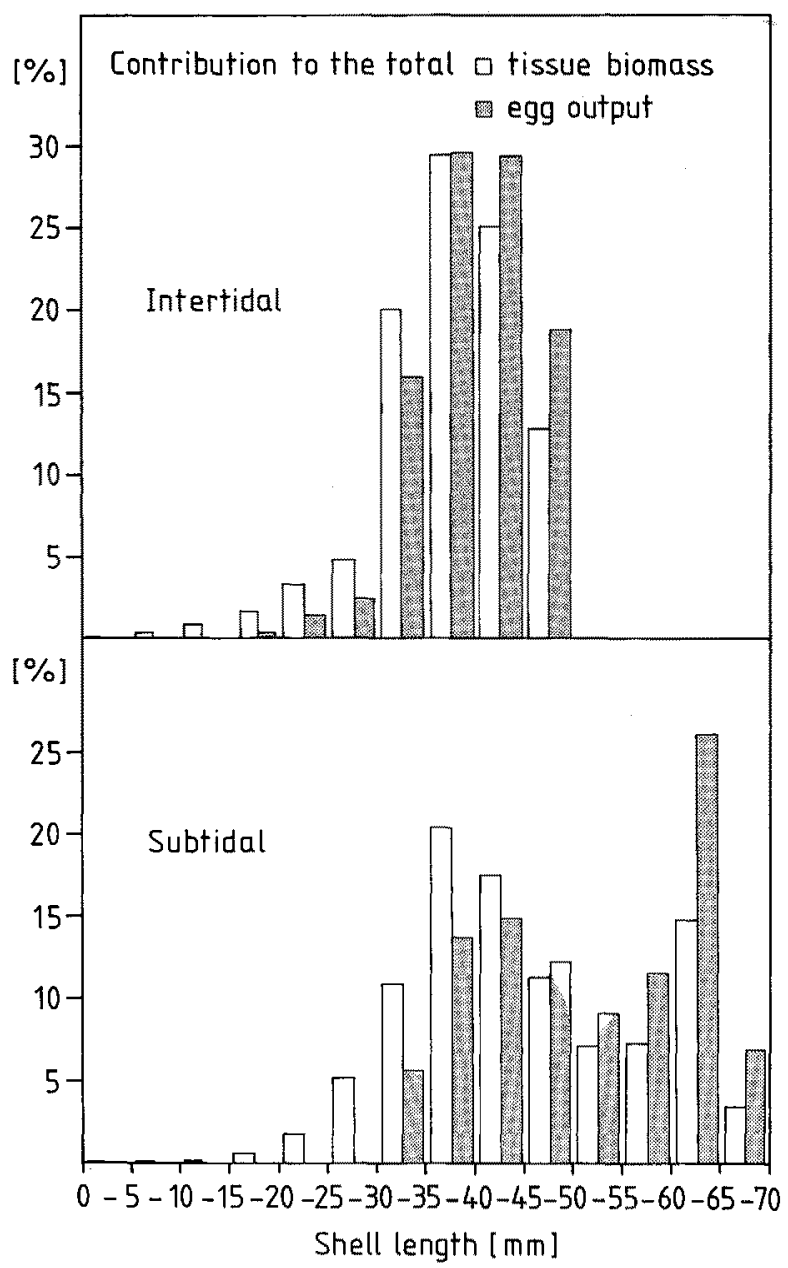

Fig. 5. Mytilus edulis: Contribution of $5 \mathrm{~mm}$ size classes to egg output and tissue biomass of the subtidal and the intertidal population (relative values); calculated from Figure 4

Most attention has been drawn to the lower limit at which gonadal activity is initiated. Only few authors stress the point that reproductive activity can be suppressed as well by high temperatures (e.g. Lubet, 1959; Wilson \& Hodgkin, 1967). In higher latitudes with a marked annual cycle, the sea temperature passes this span twice. Consequently, two spawning periods have been reported especially of European mussels in the southern regions of their occurrence e.g. in France and Spain (see Lubet, 1959; Pilar-Aguirre, 1979). Even in British waters two spawning periods have been observed during warm summers (Campbell, 1969; Seed \& Brown, 1975; Lowe et al., 1982).

However, temperature is not the only factor controlling the reproduction of Mytilus. As Bayne \& Worrall (1980) pointed out, gametogenesis is only initiated at a certain temperature if sufficient nutrient reserves within the animal or food in the environment 
Table 1. Mytilus edulis. Critical temperatures in the gonad cycle in European waters as reported by various authors

\begin{tabular}{|ccll|}
\hline $\begin{array}{c}\text { Gametogenetic } \\
\text { activity }\end{array}$ & Spawning & \multicolumn{1}{c|}{ Locality } & Authority \\
\hline$>7^{\circ} \mathrm{C}$ & $>9.5^{\circ}-12.5^{\circ} \mathrm{C}$ & England & Chipperfield (1953) \\
- & $>10^{\circ} \mathrm{C}$ & France (Atlantic Coast) & Bouxin (1954) \\
$>7^{\circ} \mathrm{C}$ & $8^{\circ}-18^{\circ} \mathrm{C}$ & France (Atlantic Coast) & Lubet (1959) \\
- & $>5.5^{\circ} \mathrm{C}$ & England (North Sea Coast) & Seed (1969) \\
$>6^{\circ} \mathrm{C}$ & - & England (Channel) & Campbell (1969) \\
\hline
\end{tabular}

are present. This may account for the absence of a second spawning period in autumn in the population examined.

Lubet $(1956,1959)$ observed that there may be a discrepancy between the morphological and physiological maturity of an animal. The positive reaction of the animal to an (obviously rather unspecific) spawning stimulus depends on the release of a neurohormone. This can explain why the mussels in the field did not spawn before the end of April, although they were already morphologically ripe in February.

Mussels are of separate sex; hermaphroditism was never observed during the course of this investigation. Lubet (1959) calculated a probability of 1:1000 for hermaphroditism. In agreement with this, Sunila (1981) found only 2 hermaphrodites among 1832 mussels examined.

Especially in the older literature a dominance of male mussels has been reported (Johnstone, 1898; Pelseneer, 1926; White, 1937; Mateeva, 1948). Sugiura (1959) found sex ratio varying with size. More recent literature agrees that males and females occur at a sex ratio of 1:1, independent of size and habitat (Lubet, 1959; Seed, 1969; PilarAguirre, 1979; Sunila, 1981). This is confirmed by the statistically insignificant difference between the frequency of male and female mussels found here.

The first onset of sexual maturation is not related to size but rather to age and growth rate (Seed, 1969). In some biotopes the mussels are only a few months old (Lubet, 1959), in others 1 year (Seed, 1969) or even older (Sunila, 1981). Consequently, the size at which Mytilus edulis attains sexual maturity varies greatly. Shell lengths reported by various authors are: $4 \mathrm{~mm}$ (Wilson, 1887), 18-22 $\mathrm{mm}$ (White, 1937; Mateeva, 1948), 15-30 $\mathrm{mm}$ (Bouxin, 1954), 5-7 mm (Lubet, 1959), 23-24 mm (rarely $10 \mathrm{~mm}$; Sugiura, 1959), 2-7 mm (Seed, 1969), $23 \mathrm{~mm}$ (Cossa et al., 1979), $35 \mathrm{~mm}$ (Pilar-Aguirre, 1979) and $2 \mathrm{~mm}$ (Kautsky, 1982).

For the populations examined it may well be that some mussels attain sexual maturity in the first year of life. According to my own observations on growth rates of mussels attached to rafts, they can grow to a shell length of $20 \mathrm{~mm}$ or more by November of the year of birth. It is known that the growth of mussels in the tidal zone is slowed down (Baird, 1966). This explains why smaller specimens were mature in the intertidal population. However, a certain part of the populations examined do not necessarily become sexually mature until the second year of life as the smaller immature animals in both populations prove.

Counts of gametes released by a mussel have been rare in the literature. Sometimes 
Table 2. Mytilus edulis. Data on numbers of eggs produced

\begin{tabular}{|rcl|}
\hline Egg number & Shell length (mm) & Authority \\
\hline $6-9 \times 10^{6}$ & $50-100$ & Field (1909) \\
$0.1-3 \times 10^{6}$ & $14-50$ & Mateeva (1948) \\
$0.5 \times 10^{6}$ & $40-50$ & Bayne et al. (1975) \\
$7.6 \times 10^{6}$ & 68 & Bayne et al. (1978) \\
\hline
\end{tabular}

Table 3. Mytilus edulis. Fecundity estimates of various authors; GW: gamete dry weight (mg); W: tissue dry weight $(\mathrm{g}) ;{ }^{*}$ calculated from weight losses

\begin{tabular}{|c|c|c|}
\hline Locality & Fecundity & Authority \\
\hline $\begin{array}{l}\text { Petpeswick } \quad \begin{array}{l}\text { in } 1974 \\
\text { in } 1975 \\
\text { in } 1977\end{array} \\
\text { Canada) } \\
\text { Lynher (United Kingdom) } \\
\text { Cattewater (United Kingdom) } \\
\text { Mothecombe (United Kingdom) } \\
\text { Helgoland (intertidal) } \\
\text { Helgoland (subtidal) }\end{array}$ & $\begin{aligned} \mathrm{GW} & =205 \mathrm{~W}^{2.638} \\
\mathrm{GW} & =305 \mathrm{~W}^{1.748} \\
\mathrm{GW} & =325 \mathrm{~W}^{1.274} \\
{ }^{*} \mathrm{GW} & =104 \mathrm{~W}^{1.40} \\
{ }^{*} \mathrm{GW} & =21 \mathrm{~W}^{1.29} \\
{ }^{*} \mathrm{GW} & =193 \mathrm{~W}^{1.51} \\
\mathrm{GW} & =530 \mathrm{~W}^{1.66} \\
\mathrm{GW} & =150 \mathrm{~W}^{1.75}\end{aligned}$ & $\begin{array}{l}\text { Thompson (1979) } \\
\text { Thompson (1979) } \\
\text { Thompson (1979) } \\
\text { Bayne \& Worrall (1980) } \\
\text { Bayne \& Worrall (1980) } \\
\text { Bayne \& Worrall (1980) } \\
\text { This study } \\
\text { This study }\end{array}$ \\
\hline
\end{tabular}

fecundity has been estimated by the loss of body weight during the spawning period (e.g. Bayne \& Worrall, 1980). Data reported are summarized in Tables 2 and 3. Egg number varies greatly with body size. The equations indicate that a 1-g mussel (shell length about $50-60 \mathrm{~mm}$ ) releases between 21 and $530 \mathrm{mg}$ gamete dry weight.

It is difficult to decide whether the gamete counts reflect the true amount of gametes the mussel produces during a spawning period. It may be an overestimation, because one tends to evaluate only the good spawners. On the other hand, it is known that mussels release gametes several times during a spawning period with intermittant recovery periods (White, 1937; Mateeva, 1948; Lubet, 1957, 1959; Seed, 1969, 1975). Thus, the true amount may well be permanently underestimated by this procedure. Furthermore, in these experiments the relatively long conditioning period of some subtidal animals may have caused some bias. However, as more precise data are lacking, these fecundity estimates must be accepted.

In contrast to the trend obtained in Figure 2, it seems doubtful that male mussels have a lower gamete output than females. Griffiths (1977) found no significant differences between female and male Choromytilus meridionalis. The trend observed may have been caused by the increased care which was taken with the females in later rearing experiments.

Conditions of life in the tidal zone are stressful, due, for example, to changes in temperature and salinity. Besides this, mussels in the tidal zone can only feed at high tide; so they suffer from shortage of food compared with those in the subtidal. As a consequence, their growth is slowed down and they attain only a smaller final size. Nevertheless, the amount of eggs released by mussels in the tidal zone is greater than 
that relased by mussels of comparable size in the subtidal. Thus, the tidal population manages to produce nearly the same egg number per unit area as the subtidal population does despite their lower biomass (see Fig. 4).

This makes sense from the ecological point of view. As I have had the chance of observing both the tidal and the subtidal populations since the beginning of $1979, \mathrm{I}$ assume that they are well established with an equilibrium of young and old animals. Mussels change their modes of growth during their life. Whereas in young animals production is confined to somatic growth, older animals tend to put more and more of their effort into reproduction. During somatic growth inter- and intraspecific competition is reduced (Theisen, 1968; Dayton, 1971; Harger, 1972; Menge \& Sutherland, 1976). Thus, under favourable conditions the "somatic period" is intensified. In contrast, stressful conditions stimulate the mussels to enhance their " reproductive period" in order to search for new grounds to settle.

From laboratory experiments it is known that stressed mussels reduce their egg size. Bayne et al. (1978) obtained egg dry weights between 22 to $129 \mathrm{ng}$. This trend is also indicated by a comparison of the egg diameter of animals from the tidal and subtidal population.

Other authors estimated the dry weight of $M$. edulis eggs as $51 \mathrm{ng}$ (Ockelmann, 1965), $52.5 \mathrm{ng}$ (Bayne et al., 1975) and $47.3 \mathrm{ng}$ (Thompson, 1979), which is in good agreement with my data.

The data on the egg output of the populations can hardly be compared with those of Griffiths (1981) and Kautsky (1982). Griffiths (1981) calculated a mean annual gamete output of a $C$. meridionalis population as $1392 \mathrm{~g} \mathrm{~m}^{-2}$ (eggs and sperm) which is about 4-5 times higher than my own data. Perhaps a species-specific as well as a geographic difference may account for a good deal of this discrepancy. The $M$. edulis population Kautsky (1982) examined was severely stressed by the low ambient salinity ( $7 \%$ ). This is manifested by an extremely slow growth. The comparatively low annual egg output $\left(8 \times 10^{7}\right.$ eggs $\left.\mathrm{m}^{-2}\right)$ is contrasted by a high weight specific fecundity (increasing from 38 to $52 \%$ of the soft body weight from 10 to $30 \mathrm{~mm}$ shell length).

Dare (1976) applied the term "carrying capacity" to describe the maximum biomass of mussels in a biotope. For the population examined he estimated a value of $1.2 \mathrm{~kg}$ dry flesh weight $\mathrm{m}^{-2}$. Griffiths (1977) quotes $790 \mathrm{~g}$ dry flesh weight $\mathrm{m}^{-2}$ for a $C$. meridionalis population. This agrees fairly well with the biomass of the intertidal population (996 $\mathrm{g}$ $\mathrm{m}^{-2}$ ). The high biomass in the subtidal $\left(2261 \mathrm{~g} \mathrm{~m}^{-2}\right)$ is presumably caused by structured surfaces sometimes allowing the formation of little ropes of mussels clinging together.

Although the biological meaning of the gamete release is to guarantee the existence of the species, the normal fate of the egg or the larva is not to grow up to a mussel, but to contribute to the nutrition of animals in the surrounding biotope. This is more pronounced for the sperms released. Assuming stable population size and that an animal will reproduce twice during its life, the probability that one egg will develop to a sexually mature animal is about the reciprocal value of the individual annual egg output (i.e. one to several million).

It is well known that a variety of marine organisms feed on mussel larvae e.g. Noctiluca miliaris, spionid larvae, zoea larvae, ctenophores (own observations), herring larvae (Lebour, 1933, Checkley, 1982) and even adult mussels (Bayne, 1964). The importance of the larvae as food organisms must be especially discussed in the light of 
their locally and temporally patchy distribution. Maximum concentrations of mussel larvae actually observed in nature range from 3 to 40 larvae per liter (e.g. Fish \& Johnson, 1937; Thorson, 1946; Rees, 1954; Schram, 1970; Hernroth \& Ackefors, 1979). From this point of view they must have some significance, especially because their occurrence coincides with that of many other meroplanktonic organisms.

Acknowledgements. My most cordial thanks are due to Dr. K. Anger for the helpful discussion of this paper, Ms. M. Eggert for aid with the field samples and Dr. M. Rieper for correcting the manuscipt. I am indebted to the Studienstiftung des deutschen Volkes, Bonn-Bad Godesberg for financial support.

\section{LITERATURE CITED}

Baird, R. H., 1966. Factors affecting the growth and condition of mussels (Mytilus edulis L.). Fishery Invest., Lond. (Ser. 2) 25, 1-33.

Bayne, B. L., 1964. Primary and secondary settlement in Mytilus edulis L. (Mollusca). - J. Anim. Ecol. 33, 513-523.

Bayne, B. L. \& Thompson, R. J., 1970. Some physiological consequences of keeping Mytilus edulis in the laboratory. - Helgoländer wiss. Meeresunters. 20, 526-552.

Bayne, B. L., Gabbott, P. A. \& Widdows, J., 1975. Some effects of stress in the adult on the eggs and larvae of Mytilus edulis L. - J. mar. biol. Ass. U. K. 55, 675-689.

Bayne, B. L., Holland, D. L., Moore, M. N., Lowe, D. M. \& Widdows, J., 1978. Further studies on the effects of stress in the adult on the eggs of Mytilus edulis. - J. mar. biol. Ass. U. K. 58, 825-842.

Bayne, B. L. \& Worrall, C. M., 1980. Growth and production of mussels Mytilus edulis from two populations. - Mar. Ecol. Prog. Ser. 3, 317-328.

Bouxin, H., 1954. Observations sur le frai de Mytilus edulis var. galloprovincialis Lmk. Dates précises de frai. Facteurs provoquant l'émission des produits génitaux. - ICES spec. scient. Meeting "Oyster and Mussel Culture" 36.

Campbell, S. A., 1969. Seasonal cycle in the carotenoid content in Mytilus edulis. - Mar. Biol. 4, 227-232.

Checkley, D. M. Jr., 1982. Selective feeding by atlantic herring (Clupea harengus) larvae on zooplankton in natural assemblages. - Mar. Ecol. Prog. Ser. 9, 245-253.

Chipperfield, P. N. J., 1953. Observations on the breeding and settlement of Mytilus edulis L. in British waters. - J. mar. biol. Ass. U. K. 32, 449-476.

Cossa, D., Bourget, E. \& Piuze, J., 1979. Sexual maturation as a source of variation in the relationship between cadmium concentration and body weight of Mytilus edulis L. - Mar. Pollut. Bull. 10, $174-176$.

Crisp, D. J., 1974. Energy relations of marine invertebrate larvae. - Thalassia jugosl. 10, 103-120.

Dare, P. J., 1976. Settlement, growth and production of the mussel, Mytilus edulis L. in Morecambe Bay, England. - Fishery Invest., Lond. (Ser. 2) 28, 1-25.

Dayton, P., 1971. Competition, disturbance and community organization: the provision and subsequent utilization of space in a rocky intertidal community. - Ecol. Monogr. 41, 351-389.

Field, I, A., 1909. The food value of the sea mussel. - Bull. U. S. Bur. Fish. 29, 85-128.

Field, I. A., 1922. Biology and economic value of the sea mussel Mytilus edulis. - Bull. U. S. Bur. Fish. 38, 127-259.

Fish, C. J. \& Johnson, M. W., 1937. The biology of the zooplankton in the Bay of Fundy and the Gulf of Maine with special reference to production and distribution. - J. biol. Bd Can. 3, 189-322.

Giese, A. C., 1959. Comparative physiology. Annual reproductive cycles of marine invertebrates. A. Rev. Physiol. 21, 547-576.

Griffiths, R. J., 1977. Reproductive cycles in littoral populations of Choromytilus meridionalis Kr. and Aulacomya ater Molina with a quantitative assessment of gamete production in the former. - J. exp. mar. Biol. Ecol. 30, 53-71.

Griffiths, R. J., 1981. Production and energy flow in relation to age and shore level in the bivalve Choromytilus meridionalis (Kr.), - Estuar, coast. mar. Sci. 13, 477-493. 
Harger, J. R. E., 1972. Variation and relative "niche" size in the sea mussel Mytilus edulis in association with Mytilus californianus. - Veliger 14, 275-282.

Hernroth, L. \& Ackefors, H., 1979. The zooplankton of the Baltic proper. A long-term investigation of the fauna, its biology and ecology. - Rep. Fishery Bd Sweden 2, 1-66.

Johnstone, J., 1898. The spawning of the mussel (Mytilus edulis). - Proc. Trans. Liverpool biol. Soc. $13,104-121$.

Kändler, R., 1926. Muschellarven aus dem Helgoländer Plankton. - Wiss. Meeresunters. (Helgoland) $16,1-8$.

Kautsky, N., 1982. Quantitative studies on gonad cycle, fecundity, reproductive output and recruitment in a baltic Mytilus edulis population. - Mar. Biol. 68, 143-160.

Kühl, H., 1972. Hydrography and biology of the Elbe estuary. - Oceanogr. mar. Biol. 10, 225-309.

Lebour, M. V., 1933. The importance of larval mollusca in the plankton. - J. Cons. perm. int. Explor. Mer 8, 335-343.

Lowe, D. M., Moore, M. N. \& Bayne, B. L., 1982. Aspects of gametogenesis in the marine mussel Mytilus edulis L. - J. mar. biol. Ass. U. K. 62, 133-145.

Lubet, P., 1956. Effets d'ablation des centres nerveux sur l'émission des gamètes chez Mytilus edulis et Chlamys varia L. - Annls Sci. nat. 18, 175-183.

Lubet, P., 1957. Cycle sexuel de M. edulis et Mytilus galloprovincialis dans le bassin d'Arcachon (Gironde). - Année biol. 33, 19-29.

Lubet, P., 1959. Recherches sur le cycle de l'émission des gamètes chez les Mytilidés et les Pectinidés. - Revue Trav. Inst. scient. tech. Pêch. marit. 23, 387-548.

Lunetta, J. E., 1969. Reproductive physiology of the mussel Mytilus perna. - Bolm Fac. Filos. Ciênc. Univ. S Paulo, 26, 33-111.

Mateeva, T. A., 1948. The biology of Mytilus edulis L. in eastern Murman. - Trudy murmansk. biol. Inst. 1, 215-241.

Menge, B. A. \& Sutherland, J. P., 1976. Species diversity gradients: synthesis of the roles of predation, competition, and temporal heterogeneity. - Am. Nat, 110, 351-369.

Mix, C. M., Hemingway, S. J. \& Schaffer, R. L., 1982. Benzo(a)pyrene concentrations in somatic and gonad tissues of bay mussels, Mytilus edulis. - Bull. environ. Contam. Toxicol. 28, 46-51.

Ockelmann, K. W., 1965. Developmental types in marine bivalves and their distribution along the Atlantic coast of Europe. In: Proceedings of the European Malacological Congress. Ed. by L. R. Cox \& J. F. Peake. Malacological Soc. of London, London 1, 25-35.

Pelseneer, P., 1926. La proportion relative des sexes chez les animaux et particulièrement chez les mollusques. - Mém. Acad. r. Belg. Cl. Sci. 8, 1-258.

Pilar-Aguirre, M. P., 1979. Biologia del mejillón (M. edulis) de cultivo de la Ria de Vigo. - Boln Inst. esp. Oceanogr. 5, 109-159.

Rees, C. B., 1954. Continuous plankton records: the distribution of lamellibranch larvae in the North Sea, 1950-51. - Bull. mar. Ecol. 4, 21-46.

Schram, J. A., 1970. Studies on the meroplankton in the inner Oslofjord. II. Seasonal differences and seasonal changes in the specific distribution of larvae. - Nytt Mag. Zool. 18, 1-21.

Seed, R., 1969. The ecology of Mytilus edulis L. (Lamellibranchiata) on exposed rocky shores. I. Breeding and settlement. - Oecologia 3, 277-316.

Seed, R., 1975. Reproduction in Mytilus (Mollusca: Bivalvia) in European waters. - Pubbl. Staz. zool. Napoli (Suppl.) 39, 317-334.

Seed, R. \& Brown, R. A., 1975. The influence of reproductive cycle, growth, and mortality on population structure in Modiolus modiolus (L.), Cerastoderma edule (L.) and Mytilus edulis L. (Mollusca: Bivalvis). In: 9th European Marine Biology Symposium. Ed. by H. Barnes. Aberdeen Univ. Press, Aberdeen, 257-274.

Sprung, M., 1980. Das Frühjahrswachstum der Miesmuschel (Mytilus edulis L.) bei kontinuierlicher und diskontinuierlicher Nahrungszufuhr im Freiland-Biotop und unter Laborbedingungen. Dipl.-Arb., Univ. Kiel, 82 pp.

Sugiura, Y., 1959. Seasonal change in sexual maturity and sexuality of Mytilus edulis. - Bull. Jap. Soc. scient. Fish. 25, 1-6.

Sunila, I., 1981. Reproduction of Mytilus edulis L. (Bivalvia) in a brackish water area, the Gulf of Finland. - Annls zool. Fenn. 18, 121-128. 
Theisen, B. F., 1968. Growth and mortality of culture mussels in the Danish wadden sea. - Meddr Danm. Fisk. - og Havunders. 6, 47-78.

Thompson, R. J., 1979. Fecundity and reproductive effort of the blue mussel (Mytilus edulis), the sea urchin (Strongylocentrotus droebachiensis), and the snow crab (Chionoectes opilio) from populations in Nova Scotia and Newfoundland. - J. Fish. Res. Bd Can. 36, 955-964.

Thorson, G., 1946. Reproduction and larval development of Danish marine bottom invertebrates. Meddr Kommn Danm. Fisk. - og Havunders. (Plankton) 4, 1-523.

Werner, B., 1940. Ober die Entwicklung und Artunterscheidung von Muschellarven des Nordseeplanktons, unter gesonderter Berüicksichtigung der Schalenentwicklung. - Zool. Jb. (Anat. Ontogenie Tiere) $66,1-54$

White, K. M., 1937. Mytilus. - L. M. B. C. Mem. typ. Br. mar. Pl. Anim. 31, 1-177.

Widdows, J., 1978. Combined effects of body size, food concentration and season on the physiology of Mytilus edulis. - J. mar. biol. Ass. U. K. 58, 109-124.

Wilson, B. R. \& Hodgkin, E. P., 1967. A comparative account of the reproductive cycles of five species of marine mussels (Bivalvia: Mytilidae) in the vicinity of Freemantle, W. Australia. Aust. J. mar. Freshwat. Res. 18, 175-203.

Wilson, J., 1887. On the development of the common mussel (Mytilus edulis L.). - Rep. Fish. Bd Scotl. 5, 247-256. 